\section{Karolinska Institute}

SwEDEN's biomedical community likes to remind visitors that of the Science Citation Index's " 1,000 Contemporary Scientists Most-Cited 1965-1978", a disproportionate 42 are Swedish and that all of these are from the biomedical sciences. The Karolinska Institute in Stockholm can lay claim to half of the $\mathbf{4 2}$.

Although effectively acting as the medical and dental schools of the University of Stockholm, the Karolinska Institute maintains a fierce independence from the university, whose existence it predates. Since 1977, all government-run medical and paramedical education in the Stockholm region has been carried out by the institute's 850 teaching and research staff. These are divided into 140 professorial departments which are very unequally divided between a north and south campus.

The former, situated just north of the city centre, has the advantages of size, power and tradition. It is where, for example, the institute's tradition of medical chemistry was begun by Jöns Jacob Berzelius, who discovered the elements Se, $\mathrm{Si}$ and Th, and introduced the system of symbols by which they are here identified. More recently the tradition has been continued by Professors Sune Bergström and Bengt Samuelsson (the institute's current president) with their discoveries of new biologically-active chemicals related to prostaglandin, itself originally discovered, at the institute by Ulf von Euler in the 1930s.

The south campus at Huddinge University Hospital, some 15 kilometres from the city centre, dates only from the 1970 s. It houses the dental school and some medical departments including the department of medical nutrition, an unlikely place to find such an indefatigable supporter of molecular biology and biotechnology as its head, Professor Jan-Åke Gustafsson.

With financial assistance from Stockholm County Council, keen to breathe new life into the economically underdeveloped southern parts of the city, Gustaffson has created the Center for Biotechnology, the 100 staff of which will pursue basic research but provide "a broad interface with industry". Within two years the centre, of which Gustaffson is managing director, will be in a new building, Novum.

A third occupant will be a new biotechnology company, KaroBio, with which Gustaffson is also involved. It will focus on infectious and bone diseases as well as steroid hormone agonists and antagonists and is financed largely by Swedish institutional investors but also by California Biotechnology Inc. The foundation of KaroBio somewhat counteracts recent decisions by Pharmacia and Astra - Sweden's largest pharmaceutical companies - to start biotechnology offshoots in California and India, respectively.
SIPRI

\section{Spawned by unbroken peace}

CRITICs of the Stockholm International Peace Research Institute (SIPRI) used to call it an organ of the 'left'. But now, and particularly in Swedish 'peace' circles, it is criticized as a "NATO institute", says its latest director Dr Walther Stützle, who until a year ago was undersecretary for defence, planning and policy for the West German government.

All of which goes to show how slippery is the definition of peace research, not least for an institute that was founded in 1966 to commemorate 150 years of unbroken peace in Sweden. It was a former prime minister of Sweden, Tage Erlander, who suggested the institute, and a Royal Commission that designed it. And it is the Swedish parliament that still provides almost all the funds - SEK 18 million this year.

Under Stützle, SIPRI's focus of research is on military realities and arms control possibilities, with an emphasis on five areas. Two of these are the traditional SIPRI topics of military expenditure and arms trade, on which the institute keeps a unique databank. The extensive information gathered in both areas is included in SIPRI's bread-and-butter project, its yearbook, which now runs to some 500 pages. Breaking with tradition, the 1987 yearbook contains no estimate of the Soviet defence budget: no reliable estimate can be produced, says Stützle.

The other three broad areas of research are the US-Soviet strategic relationship, European security and arms control, and weapons technology and arms control. Within these fields some studies are devoted to issues that are of immediate relevance to policy, while others deal with issues that are more in the background. It is much harder now than it must have been in 1966 to carve out a niche for SIPRI, says Stützle, because of the burgeoning of a neutral country remains an advantage when it comes to persuading Eastern bloc delegates to the small seminars that are another of SIPRI's activities; there is an ambitious plan, for example, to bring together actively-serving experts on threat

\section{An ISCOM from SLU}

Bror Morein of the Swedish University of Agricultural Sciences (SLU) at the Biomedical Centre in Uppsala has pioneered the development of vaccines based on immuno-stimulating complex (ISCOM) particles. The matrix of the cage-like particles is composed of Quil A, which is extracted from the bark of a South American tree. Antigenic proteins attached by hydrophobic interactions to the surface of the matrix evoke a strong immune response. peace research. The institute's location in assessment from the military establishments of the east and west.

Chemical and biological warfare (CBW) issues have always been on SIPRI's agenda. They are now under Johan Lundin, a physiologist previously employed at the Swedish National Defence Research Institute, and an erstwhile Swedish delegate to the CBW negotiations in Geneva. One aim of his group's research is to define verification systems that would be acceptable to the chemical industry, given the need for normal commercial and technical secrecy.

One of Stützle's favourite projects is an example of "what if"? research, an

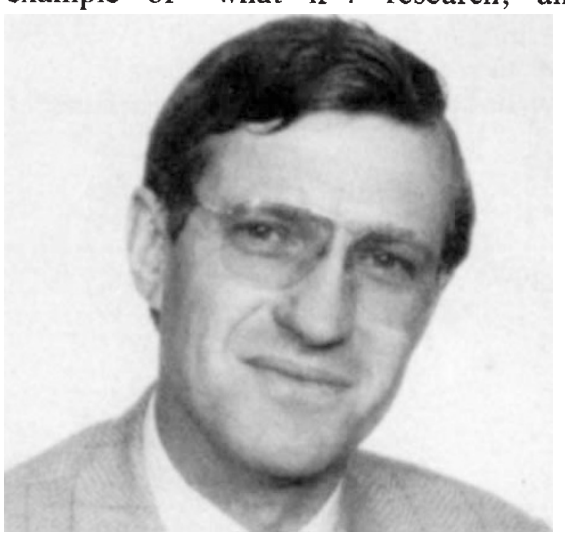

SIPRI director Walther Stützle - treading the delicate line between the right and left of peace.

approach that SIPRI can afford to take. The question is what would be the effects both for Europe and the United States if US armed forces were to be removed from Europe. This project is supported by the MacArthur Foundation in Chicago, and Stützle hopes for more external support to counter a decreasing budget in real terms from the Swedish parliament. Like other European research directors he finds it impossible to compete with salaries that can be offered the most prestigious US universities, and yet is loath to settle for less than the best researchers.

Does SIPRI have any connection with the Nobel peace prize? No, says its director, except that it hopes to win one, "but that would only happen long after my time!" 